\title{
Social Capital and Factors Related to Stroke Risk in Ponorogo Hospital: Structural Equation Model Application
}

\author{
Lailatul Rohmah'), Setyo Sri Rahardjo), Bhisma Murti1) \\ 1)Masters Program in Public Health, Universitas Sebelas Maret \\ ${ }^{2)}$ Faculty of Medicine, Universitas Sebelas Maret
}

\section{ABSTRACT}

Background: Stroke is a non-communicable disease that ranks the second leading cause of death in the world. As many as 17 million patients who suffered a stroke, 6.5 million died from a stroke. This disease cannot be cured but can be controlled. The increasing number of cases of non-communicable diseases is related to risk factors. This study aimed to analyze the effect of social capital and factors related to stroke risk.

Subjects and Method: A case-control study was conducted at the Ponorogo District Hospital, East Java, from February to March 2020. A sample of 200 patients was taken through fixed disease sampling. The dependent variable was a stroke. The independent variables were social capital, hypertension, residence, workplace, stress, income, dietary habit, education, physical activity. The data was collected using a questionnaire. Data were analyzed using the Structural Equation Model run on Stata 13.

Results: The increase in stroke was directly affected by hypertension $(b=2.90 ; 95 \% \mathrm{CI}=$
2.09 to $3.71 ; \mathrm{p}<0.001)$. The risk of stroke was affected indirectly by social capital, hypertension, workplace, stress, income, dietary habit, education, physical activity. Trust, bonding, bridging, and linking indirectly affected stroke risk on the contribution of social capital measurement.

Conclusion: Increased stroke is directly affected by hypertension. Stroke is indirectly affected by social capital, hypertension, workplace, stress, income, dietary habits, education, and physical activity. Trust, bonding, bridging, and linking indirectly affect stroke risk on the contribution of social capital measurement.

Keywords:stroke, social capital, risk factors

\section{Correspondence:}

LailatulRohmah. Masters Program in Public Health, Universitas Sebelas Maret. Jl. Ir. Sutami 36A, Surakarta 57126, Central Java. Email: rohmalailatul156@gmail.com. Mobile: +6289691804847.

\section{Cite this as:}

Rohmah L, Rahardjo SS, Murti B (2020). Social Capital and Factors Related to Stroke Risk in Ponorogo Hospital: Structural Equation Model Application. J Epidemiol Public Health. 05(03): 258-269. https://doi.org/10.26911/jepublichealth.2020.05.03.01

(7) (7) Journal of Epidemiology and Public Healthis licensed under a Creative Commons EY AC Attribution-NonCommercial-ShareAlike 4.o International License.

\section{BACKGROUND}

Non-communicable diseases kill 41 million people every year or the equivalent of $71 \%$ of deaths globally. One of the four main types of non-communicable diseases, according to WHO, is cardiovascular disease, namely coronary heart disease and stroke. Stroke is a non-communicable disease that ranks the second leading cause of death in the world (WHO, 2018). As many as 17 million patients suffered a stroke, 6.5 million died from a stroke (WHO, 2017).

Global Burden of Disease states that death's standard based on age and sex has a wide reach in Asia. The highest mortality rates can be seen in Mongolia (222.6/ 100,000 people per year) and Indonesia (193.3/ 100,000 people per year), followed by Myanmar and North Korea (Venketasubramanian et al., 2017). 
Stroke is in the first position as a disease that causes death in Indonesia. The prevalence of stroke in Indonesia in 2018 has increased from $7 \%$ to $10.9 \%$, which has increased by $3.9 \%$ in the last 5 years (Research and Development Agency Ministry of Health, 2018). The prevalence of stroke cases in Indonesia based on a doctor's diagnosis is 10.9 per mile for those diagnosed with stroke symptoms. The highest cases occurred in East Kalimantan Province (14.7\%), and the lowest was in Papua Province (4.1\%), while East Java Province was 11.5\% (Basic Health Research, 2018).

According to Mutiarasari (2019), an unhealthy lifestyle, such as foods high in fat and high in cholesterol, lack of physical activity and exercise, can increase the risk of having a stroke. Lifestyle is often the cause of diseases that attack productive age because young people often adopt unhealthy diets. In addition to consuming a lot of cholesterol, they consume excessive sugar, which will cause obesity, which results in the accumulation of fat in the body. Some of the most important risk factors are hypertension, diabetes mellitus, obesity, and heart disease. One of the efforts to reduce stroke incidence by early prevention in stroke patients is very important, both before and after an attack.

According to Palafox et al. (2017), several aspects of social capital are associated with better hypertension management in low-income countries where health systems are often weak. Given that hypertension affects millions of people in these countries, that moderate increase at all points along the treatment pathway can improve management for many people and prevent thousands of cardiovascular events each year.

Prevention is one of the most effective and efficient ways to reduce the incidence of stroke. In Indonesia, stroke control guidelines state that early detection of stroke risk factors plays a major role in controlling efforts and determining the prognosis for stroke in the next five years (Ministry of Health Stroke Control Guidelines, 2013).

The explanation above shows that the incidence of stroke in several regions of Indonesia has increased significantly from time to time. It is expected that social capital and stroke risk are needed to detect as early as possible in preventing stroke. This study aims to analyze social capital and the factors that affect stroke risk.

\section{SUBJECTS AND METHOD}

\section{Study Design}

This study was analytic observational with a case-control design. This study was conducted at the Ponorogo Regional Public Hospital, East Java, from February to March 2020.

\section{Population dan Sample}

The population in this study were stroke patients and non-stroke patients at the Ponorogo Regional Public Hospital. A sample of 200 patients was taken using the fixed disease sampling technique.

\section{Study Variables}

The dependent variable was a stroke. The independent variables were social capital, hypertension, residence, workplace index, stress, income, dietary habit, education, physical activity, trust, bonding, bridging, and linking.

\section{OperationalDefinition of Variables}

Stroke was a condition that occurs when the blood supply to the brain was interrupted or reduced due to blockage or rupture of blood vessels. The instrument used was a questionnaire. The data scale was continuous, but for analysis, the data was converted into a dichotomy, coded $\mathrm{o}=$ no stroke $1=$ stroke. 
Social Capital was the correlation between individuals and groups/communities. The instrument used was a questionnaire. The data scale was continuous, but it was transformed into dichotomous, coded $\mathrm{O}=$ weak $1=$ strong.

Hypertension was someone who had been declared hypertensive and was registered and reported to the health office, where the blood pressure exceeds the normal limit, systolic $\geq 140 \mathrm{mmHg}$, and diastolic $\leq 90 \mathrm{mmHg}$. The instrument used was a questionnaire using a doctor's diagnosis. The data scale was continuous, but for analysis, the data was converted into a dichotomy, coded $\mathrm{o}=$ normal $1=$ high blood pressure.

The residence was the address where the respondent lives. The instrument used was a questionnaire. The data scale was continuous, but for analysis, the data was converted into a dichotomy, coded $0=$ rural $1=$ urban.

Workplace index was a good quality work related to a work atmosphere, good treatment, a sense of security, and a harmonious correlation. The instrument used was a questionnaire. The data scale was continuous, but it was transformed into dichotomous, $\operatorname{coded} 0=\operatorname{good} 1=$ bad.

Stress was a measurement of respondents' pressure or demands to adapt and adjust to life changes or life events experienced in the last 1 year before being sick. The instrument used was a questionnaire. The data scale was continuous, but it was transformed into dichotomous, coded $0=$ normal $1=$ experiencing stress.

Income was the amount of money received by the respondent per month. The instrument used was a questionnaire. The data scale was continuous, but it was transformed into dichotomous, coded $0=$ low $1=$ high . The dietary habit was the habit of respondents before being sick in consuming food ingredients that trigger strokes, such as foods containing salt and fat. The instrument used was a questionnaire. The data scale was continuous, but it was transformed into dichotomous, coded $\mathrm{O}=\operatorname{good} 1=$ bad.

Education is the highest level of formal education that the respondent had completed based on its recognition. The instrument used was a questionnaire. The data scale was continuous, but for analysis, the data was converted into a dichotomy, coded $\mathrm{O}=$ low $1=$ high .

Physical activity was the body's movement that used energy that was done daily before the respondent got sick. The instrument used was a questionnaire. The data scale was continuous, but it was transformed into dichotomous, coded $0=$ low $1=$ high. Bonding was the correlation between individuals in reacting and interacting with others. The instrument used was a questionnaire. The data scale was continuous, but it was transformed into dichotomous, coded $0=$ weak $1=$ strong.

Bridging was people or other individuals who affected the individual, generally in input from outside the person, both from family and group. The instrument used was a questionnaire. The data scale was continuous, but it was transformed into dichotomous, $\operatorname{coded} \mathrm{O}=$ weak $1=$ strong.

Linking was an individual who could affect the group. The instrument used was a questionnaire. The data scale was continuous, but it was transformed into dichotomous, coded $0=$ weak $1=$ strong.

Trust was mutual trust in society. The instrument used was a questionnaire. The measurement scale was continuous, but it was transformed into dichotomous, coded $\mathrm{O}=$ weak $1=$ strong.

\section{Data Analysis}

Univariate analysis was performed on each study variable. Categorical data were 
described in the frequency distribution table. A continuous sample of data characteristics as described in the parameters $\mathrm{n}$, mean, SD, minimum, and maximum.

The bivariate analysis in this study used the Chi-square test. This test was to determine the correlation between variables.

Multivariate analysis was to determine the effects of various variables studied using structural equation modeling using the application of stata 13 .

\section{Research Ethic}

This study was conducted based on a study of research ethics, namely consent, anony- mity, confidentiality, and ethical reviews. Research ethics approval was obtained from the health research ethics committee at Dr. Hardjono, Ponorogo, Indonesia, no: 3502021K112142020012000007/KEPK/2020.

\section{RESULTS}

\section{A. Sample Characteristics}

Table 1 shows the sample characteristics (continuous data). Categorical data are described in Table 2.

Table 1. Sample Characteristics (continuous data)

\begin{tabular}{llllll}
\hline Variable & N & Mean & Std. Dev & Min. & Max. \\
\hline Age (years) & 200 & 53.93 & 12.60 & 27 & 75 \\
Workplace index & 200 & 6.44 & 1.85 & 2 & 11 \\
Income (rupiah) & 200 & $1,215,500$ & $694,999.9$ & 500,000 & 3, Ooo,ooo \\
Systole (mm / Hg) & 200 & 127.5 & 14.23 & 100 & 200 \\
Diastole (mm / Hg) & 200 & 79.15 & 11.10 & 60 & 130 \\
Stress & 200 & 11.32 & 3.75 & 7 & 21 \\
Physical activity & 200 & $4,863.45$ & $1,745.62$ & 1,020 & 9,495 \\
Dietary habit & 200 & 9.79 & 4.17 & 3 & 22 \\
Trust & 200 & 8.93 & 2.97 & 3 & 12 \\
Bonding & 200 & 6.20 & 1.95 & 1 & 8 \\
Bridging & 200 & 5.86 & 2.03 & 1 & 8 \\
Linking & 200 & 4.55 & 1.63 & 1 & 6 \\
\hline
\end{tabular}

\section{B. Univariate analysis}

Table 2 shows the univariate analysis data (dichotomous data) of 200 female subjects, as many as 101 people (50.5\%). The majority of the study was 160 people aged $\geq 45$ years (80.0\%), with education level $<$ senior high school as many as 143 people (71.5\%). The majority of study subjects live in rural areas were 148 people (74.0\%), good workplace index was 119 people (59.5\%), and with an income $<$ Regional Minimum Wage as many as 135 people (67.5\%). The majority of study subjects did not have hypertension as many as 133 people (66.5\%), did not experience stress as many as 128 people (64.0\%), had a physical activity in the high category as many as 133 people (66.5\%), and had a good diet as many as 156 people (78.0\%).

\section{The result of bivariate analysis}

Table 3 shows the results of the Chi square test. The risk of stroke occured when education $<$ senior high school (OR= 0.16; 95\% $\mathrm{CI}=0.04$ to $0.47 ; \mathrm{p}<0.001)$, poor workplace index $(\mathrm{OR}=37.78 ; 95 \% \mathrm{CI}=12.28$ to 151.18; $\mathrm{p}<0.001$ ), income < Regional Minimum Wage $(\mathrm{OR}=0.21 ; 95 \% \mathrm{CI}=0.06$ to 0.54; $\mathrm{p}<0.001)$, hypertension $(\mathrm{OR}=18.22$; $95 \% \mathrm{CI}=7.65$ to $45.2 ; \mathrm{p}<0.001)$, stress $(\mathrm{OR}=12.57 ; 95 \% \mathrm{CI}=5.49$ to $29.89 ; \mathrm{p}$ $<0.001)$, low physical activity $(\mathrm{OR}=0.15$; 95\% CI $=0.07$ to 0.32 ; $\mathrm{p}<0.001)$, poor dietary habit $(\mathrm{OR}=45.64 ; 95 \% \mathrm{CI}=16.39$ to 132.74; $\mathrm{p}<0.001)$. 
Rohmah et al./ Social Capital and Factors Related to Stroke Risk

Table 2. Sample Characteristics (categorical data)

\begin{tabular}{llll}
\hline Variable & Criteria & N & \% \\
\hline Stroke & No & 150 & 75.0 \\
Sex & Yes & 50 & 25.0 \\
& Female & 101 & 50.5 \\
Age (years) & Male & 99 & 49.5 \\
& $<45$ years & 40 & 20.0 \\
Education & $\geq 45$ years & 160 & 80.0 \\
& < Senior High School & 143 & 71.5 \\
Residence & $\geq$ Senior High School & 57 & 28.5 \\
\multirow{2}{*}{ Workplace index } & Rural & 148 & 74.0 \\
& Urban & 52 & 26.0 \\
Income & Good & 119 & 59.5 \\
& Poor & 81 & 40.5 \\
Hypertension & $<$ Regional Minimum Wage & 135 & 67.5 \\
\multirow{2}{*}{ Stress } & $\geq$ Regional Minimum Wage & 65 & 22.5 \\
& No & 133 & 66.5 \\
Physical activity & Yes & 67 & 33.5 \\
\multirow{2}{*}{ Dietary habit } & Normal & 128 & 64.0 \\
& Stress & 72 & 36.0 \\
\hline
\end{tabular}

Table 3. Bivariate analysis of social capital and factors related to stroke risk

\begin{tabular}{|c|c|c|c|c|c|c|c|c|}
\hline \multirow[t]{2}{*}{ Independent variables } & \multicolumn{2}{|c|}{ Did not stroke } & \multicolumn{2}{|c|}{ Stroke } & \multicolumn{2}{|c|}{ Total } & \multirow[t]{2}{*}{ OR } & \multirow[t]{2}{*}{$\mathbf{p}$} \\
\hline & $\mathbf{N}$ & \% & $\mathbf{N}$ & \% & $\mathbf{N}$ & \% & & \\
\hline \multicolumn{9}{|l|}{ Education } \\
\hline$<$ Senior High School & 97 & 67.83 & 46 & 32.17 & 143 & 100 & 0.16 & $<0.001$ \\
\hline $\begin{array}{l}\geq \text { Senior High School } \\
\text { Residence }\end{array}$ & 53 & 92.98 & 4 & 7.02 & 57 & 100 & & \\
\hline Rural & 111 & 75.00 & 37 & 25.00 & 148 & 100 & 1 & 1.000 \\
\hline Urban & 39 & 75.00 & 13 & 25.00 & 52 & 100 & & \\
\hline \multicolumn{9}{|l|}{ Workplace index } \\
\hline Good & 115 & 96.64 & 4 & $3 \cdot 36$ & 119 & 100 & 37.78 & $<0.001$ \\
\hline Poor & 35 & 43.21 & 46 & 56.79 & 81 & 100 & & \\
\hline \multicolumn{9}{|l|}{ Income } \\
\hline$<$ Regional Minimum Wage & 91 & 67.41 & 44 & 32.59 & 135 & 100 & 0.21 & $<0.001$ \\
\hline $\begin{array}{l}\geq \text { Regional Minimum Wage } \\
\text { Hypertension }\end{array}$ & 59 & 90.77 & 6 & 9.23 & 65 & 100 & & \\
\hline No & 133 & 92.48 & 10 & 7.52 & 133 & 100 & 18.22 & $<0.001$ \\
\hline Yes & 27 & 40.30 & 40 & 59.70 & 67 & 100 & & \\
\hline \multicolumn{9}{|l|}{ Stress } \\
\hline Normal & 117 & 91.41 & 11 & 8.59 & 128 & 100 & 12.57 & $<0.001$ \\
\hline Stressed & 33 & 45.83 & 39 & 54.17 & 72 & 100 & & \\
\hline \multicolumn{9}{|l|}{ Physical activity } \\
\hline High & 116 & 87.22 & 17 & 12.78 & 133 & 100 & 0.15 & $<0.001$ \\
\hline Low & 34 & 50.75 & 33 & 49.25 & 67 & 100 & & \\
\hline \multicolumn{9}{|l|}{ Dietary habit } \\
\hline Good & 142 & 91.03 & 14 & 8.97 & 156 & 100 & 45.64 & $<0.001$ \\
\hline Poor & 8 & 18.18 & 36 & 81.82 & 44 & 100 & & \\
\hline
\end{tabular}

\section{D.The result of multilevel analysis}

Multivariate analysis was used to see the effects of more than one independent varia- ble. The method used was the Structural Equation Model using Stata 13. 
Figure 1 shows the direct and indirect effects of variables on stroke risk.

Table 4 shows that there was a direct effect on hypertension on stroke risk.

\section{Association between hypertension} and stroke risk

A person with hypertension had a logodd (likelihood) of having a stroke 2.90 units higher than someone without hypertension $(b=2.90 ; 95 \% \quad C I=2.09$ to $3.71 ; \quad p=$ $<0.001)$.

The correlation between stress and hypertension

A person with stress had a logodd (likelihood) of having hypertension 1.04 units higher than someone who did not experience stress $(b=1.04 ; 95 \% \mathrm{CI}=0.24$ to $1.85 ; \mathrm{p}=$ o.011).

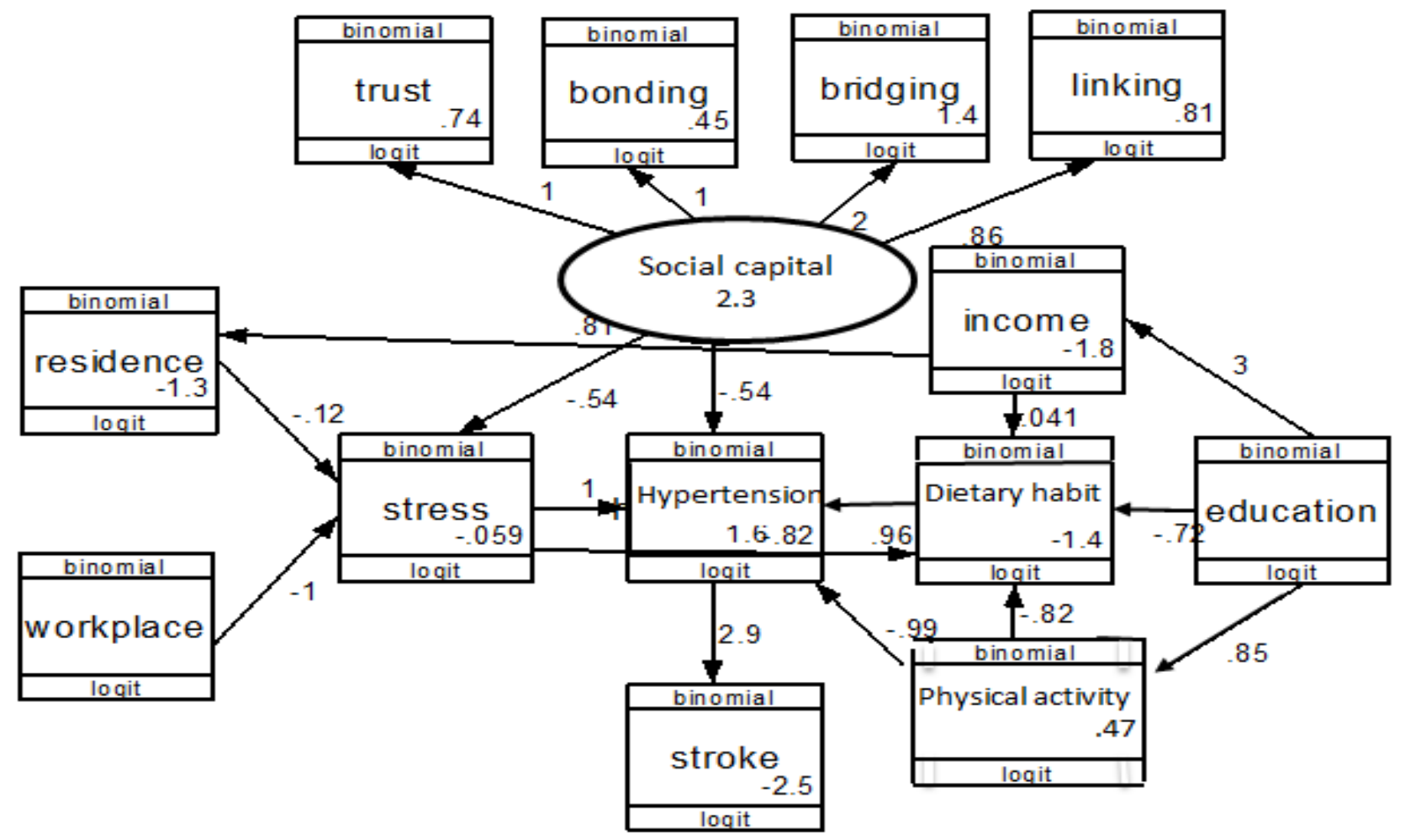

Figure 1. Structural Model of Path Analysis

The correlation between dietary habit and hypertension

A person with a poor diet had a logodd (probability) of having hypertension 0.95 units higher than someone with a good diet $(b=0.95 ; 95 \% \mathrm{CI}=0.03$ to $1.87 ; \mathrm{p}=0.041$ ).

The correlation between physical activity and hypertension

A person with high physical activity had a logodd (probability) of having hypertension -0.99 units lower than someone with low physical activity $(b=-0.99 ; 95 \% \mathrm{CI}=-1.75$ to $-0.22 ; p=0.011)$.
The correlation between social capital and hypertension

A person with strong social capital had a logodd (probability) of having hypertension -0.54 units lower than someone with weak social capital $(b=-0.54 ; \mathrm{CI}=95 \%-0.99$ to o.08; $\mathrm{p}=0.020$ ).

The correlation between the workplace index and stress

A person thatworked in a good workplace had a logodd (likelihood) of experiencing stress -1.04 units lower than someone 
working in a good workplace $(\mathrm{b}=-1.04$; $95 \% \mathrm{CI}=-1.76$ to $-0.32 ; \mathrm{p}=0.005$ )

The correlation between social capital and stress

Someone with strong social capital had a logodd (probability) to experience stress 0.54 units lower than someone with weak social capital $(b=-0.54 ; \mathrm{CI}=95 \%-0.97$ to $0.11 ; \mathrm{p}=0.011$ ).

The correlation between stress and dietary habit

A person with stress had a logodd (likelihood) of having a bad diet 1.60 units higher than someone without stress $(b=1.60 ; 95 \%$ $\mathrm{CI}=0.85$ to $2.35 ; \mathrm{p}<0.001)$.

Table 4. The analysis results of social capital pathways and factors associated with stroke risk: Application of Structural Equation Model

\begin{tabular}{|c|c|c|c|c|c|c|}
\hline \multirow{2}{*}{\multicolumn{2}{|c|}{ Dependent variable }} & \multirow[b]{2}{*}{ Independent variable } & \multirow{2}{*}{$\begin{array}{c}\text { Path } \\
\text { Coeffi- } \\
\text { cient (b) }\end{array}$} & \multicolumn{2}{|c|}{$95 \% \mathrm{CI}$} & \multirow[b]{2}{*}{$\mathbf{p}$} \\
\hline & & & & Lower & Upper & \\
\hline \multicolumn{7}{|l|}{ Direct Effect } \\
\hline Stroke & $\leftarrow$ & Hypertension (yes) & 2.90 & 2.09 & 3.71 & $<0.001$ \\
\hline \multicolumn{7}{|l|}{ Indirect Effect } \\
\hline \multirow[t]{4}{*}{ Hypertension } & $\leftarrow$ & Stress (yes) & 1.04 & 0.24 & 1.85 & 0.011 \\
\hline & $\leftarrow$ & Dietary habit (poor) & 0.95 & 0.03 & 1.87 & 0.041 \\
\hline & $\leftarrow$ & Physical activity (high) & -0.99 & -1.75 & -0.22 & 0.011 \\
\hline & $\leftarrow$ & Social capital (strong) & -0.54 & -0.97 & -0.08 & 0.020 \\
\hline \multirow[t]{3}{*}{ Stress } & $\leftarrow$ & Residence (urban) & -0.12 & -0.88 & 0.64 & 0.754 \\
\hline & $\leftarrow$ & Workplace index (good) & -1.04 & -1.76 & -0.32 & 0.005 \\
\hline & $\leftarrow$ & Social capital (strong) & -0.54 & -0.97 & -0.11 & 0.014 \\
\hline \multirow{4}{*}{$\begin{array}{l}\text { Dietary habit } \\
\text { (poor) }\end{array}$} & $\leftarrow$ & Stress (yes) & 1.60 & 0.85 & 2.35 & $<0.001$ \\
\hline & $\leftarrow$ & Education ( $\geq$ Senior High School) & -0.71 & -1.83 & 0.40 & 0.209 \\
\hline & $\leftarrow$ & Physical activity (low) & -0.81 & -1.56 & -0.07 & 0.031 \\
\hline & $\leftarrow$ & $\begin{array}{l}\text { Income ( } \geq \text { Regional Minimum } \\
\text { Wage) }\end{array}$ & 0.04 & -0.97 & 1.05 & 0.936 \\
\hline Physical activity & $\leftarrow$ & Education ( $\geq$ Senior High School) & 0.85 & 0.13 & 1.57 & 0.020 \\
\hline \multicolumn{7}{|l|}{$\begin{array}{l}\text { ( } \geq \text { Regional } \\
\text { Minimum Wage) }\end{array}$} \\
\hline Residence & $\leftarrow$ & $\begin{array}{l}\text { Income ( } \geq \text { Regional Minimum } \\
\text { Wage) }\end{array}$ & 0.80 & 0.15 & 1.45 & 0.016 \\
\hline Social capital & $\leftarrow$ & Bonding & 1 & 0.04 & 0.85 & 0.031 \\
\hline Social capital & $\leftarrow$ & Bridging & 2.03 & 0.12 & 3.93 & 0.037 \\
\hline Social capital & $\leftarrow$ & Linking & 0.85 & 0.30 & 1.40 & 0.002 \\
\hline Social capital & $\leftarrow$ & Trust & 1.01 & 0.33 & 1.66 & 0.003 \\
\hline \multicolumn{7}{|c|}{$\mathrm{N}$ Observation $=200$} \\
\hline \multicolumn{7}{|c|}{ Log Likelihood= -1178.94 } \\
\hline
\end{tabular}

The correlation between physical activity and dietary habit

A person with low physical activity had a logodd (likelihood) of experiencing a bad diet -0.81 unit higher than someone with high physical activity $(\mathrm{b}=-0.81 ; 95 \% \mathrm{CI}=-$ 1.56 to $-0.07 ; \mathrm{p}=0.031$ ).
The correlation between education and physical activity

A person with education level $\geq$ Senior High School education had a logodd (likelihood) of experiencing high physical activity 0.85 units higher than someone with an educa- 
tion level $<$ Senior High School $(b=0.85$; $95 \% \mathrm{CI}=0.13$ to $1.57 ; \mathrm{p}=0.020$ ).

The correlation between education and income

A person with education level $\geq$ Senior High School had a logodd (probability) to get an income of $\geq$ Regional Minimum Wage 2.97 units higher than someone with an education level<Senior High School (b = 2.97; 95\% CI 2.20 to 3.75 ; $\mathrm{p}<0.001$ ).

The correlation between income and residence

A person with an income $\geq$ Regional Minimum Wage had a logodd (probability) to experience living in a city o.80 units higher than someone with an income <Regional Minimum Wage $(b=0.80 ; 95 \% \mathrm{CI}=0.15$ to $1.45 ; \mathrm{p}=0.016)$.

Bonding contribution in measuring social capital

Strong bonding gave a logodd (probability) contribution to strong social capital by 1 unit higher than weak bonding $(b=1 ; 95 \%$ $\mathrm{CI}=0.04$ to $0.85 ; \mathrm{p}=0.031$ ).

Bridging contribution in measuring social capital

Strong bridging gave logodd (probability) contribution to strong social capital by 2.03 units higher than weak bridging $(\mathrm{b}=2.03$; 95\% $\mathrm{CI}=0.12$ to $3.93 ; \mathrm{p}=0.037$ ).

Linking contribution to measuring social capital

Strong linking gave logodd (probability) contribution to strong social capital by 0.85 units higher than weak linking $(b=0.85$; 95\% CI= 0.30 to $1.40 ; \mathrm{p}=0.002$ ).

Trust contribution in measuring social capital

Strong trusts gave logodd (probability) of contribution to strong social capital by 1.01 units higher than weak trusts $(b=1.01 ; 95 \%$ $\mathrm{CI}=0.33$ to $1.66 ; \mathrm{p}=0.003$ ).

\section{DISCUSSION}

1. The effect of hypertension on stroke

The results of the analysis in this study showed that hypertension had a direct effect on stroke risk. There was a positive correlation between hypertension and stroke risk, and this effect was statistically significant.

Hypertension is the important factor and a major risk factor in the incidence of ischemic and hemorrhagic strokes. Besides, high blood pressure is also associated with an increased risk of early stroke recurrence (Appleton et al., 2016).

According to a study conducted by Monica, Widyaningsih, and Sulaeman (2019), there was a significant effect between hypertension and stroke risk ( $p$ $<0.001)$. A person who had hypertension was 6.6 times more likely to have a stroke risk at a young age than someone who did not have hypertension.

\section{The effect of education on stroke}

The results of the analysis in this study showed that education had an indirect effect on stroke risk. There was a positive correlation between education and stroke risk, and this effect was statistically significant.

A person who has a higher education level can prevent early symptoms of a stroke $(\mathrm{p}=0.006)$ (Wardhani and Martini, 2014).

\section{Effect of residence on stroke}

The analysis results in this study showed that the place of residence had an indirect effect on stroke risk. There was a negative correlation between residence and stroke risk, and this effect was not statistically significant.

AHD (2014) did not support the statement that stroke frequently occurred in urban areas. This occurred because there had been a shift in behavior patterns 
(lifestyle). This study is consistent with a study conducted by Susilawati and Nurhayati (2018), which stated that there was no correlation between residence and stroke $(\mathrm{p}=0.400)$.

\section{The effect of workplace index on stroke}

The analysis results in this study showed that the workplace index had an indirect effect on stroke risk. There was a negative correlation between workplace index and stroke risk and this effect was statistically significant.

A safe and healthy workplace will have a positive impact on the people in it. A safe workplace atmosphere, good treatment, and harmonious correlation would increase productivity because it decreased the number of days lost, increased the efficiency and quality of more committed workers. This was stated by Rivai (2009) (Narianggono et al., 2014).

\section{The effect of income on stroke}

The results of the analysis in this study showed that income had an indirect effect on stroke risk. There was a positive correlation between income and stroke risk, and this effect was statistically significant.

The income of the head of the family had a positive effect on good health status. The number of family members affected good health status. If there are more than three household members, the better the health condition is from each level of income of the family (Puluhulawa, 2019).

\section{Effect of stress on stroke}

The results of the analysis in this study showed that stress had an indirect effect on stroke risk. There was a positive correlation between stress and stroke risk, and this effect was statistically significant.

This study is supported by a study conducted by Udani (2013), which stated that stress affected the incidence of a stroke. Someone who experienced stress had 3.08 times stroke risk than someone who did not experience stress $(\mathrm{OR}=3.08$; $\mathrm{p}=0.008$ ).

Other studies also suggest that there was an effect of stress on stroke risk. A person who experienced stress had 3.78 times the risk of having a stroke compared to someone who did not experience stress $(\mathrm{OR}=3.78 ; 95 \% \mathrm{CI}=0.01-0.11 ; \mathrm{p}<0.001)$ Marbun, Juanita and Ariani (2016).

\section{The effect of physical activity on stroke}

The analysis results in this study showed that physical activity had a direct effect on stroke risk. There was a negative correlation between physical activity and stroke risk and this effect was statistically significant.

According to WHO (2018), physical activity is defined as anybody movement produced by skeletal muscles that require energy, including activities carried out while working, playing, doing household chores, traveling, and doing recreational activities.

Other studies also suggested that there was an effect between low physical activity and the risk of stroke. Someone who did low physical activity had a stroke risk of 11.3 times compared to someone who did the moderate physical activity $(\mathrm{OR}=11.3 ; 95 \% \mathrm{CI}=2.7-47.6 ; \mathrm{p}<0.001)$ (Yulendasari R, 2017).

\section{The effect of diet on stroke}

The results of the analysis in this study showed that diet had an indirect effect on stroke risk. There was a positive correlation between diet and stroke risk and this effect was statistically significant.

The DASH (Dietary Approaches to Stop Hypertension) diet can reduce and control blood pressure by reducing salt intake, saturated fat and cholesterol (Utami, 2015). 
This study is in line with a study conducted by Susilawati and Nurhayati (2018), which showed a significant effect of dietary factors on stroke. Someone who ate a diet high in salt, sugar and fat had a risk of having a stroke 1.03 times than someone who did not eat a diet high in salt, sugar and fat $(\mathrm{OR}=1.03 ; \mathrm{p}<0.001)$.

\section{The effect of social capital on stroke}

The analysis results in this study showed that social capital had an indirect effect on stroke risk. There was a negative correlation between social capital and stroke risk and this effect was statistically significant.

According to Maulidia and Hidayati (2019), health was affected by social capital. Religious leaders, community leaders, village communities and health workers maintain cooperation in routine program activities and the establishment of village health institutions. The community and health workers strongly maintain social capital. This is reflected in the community's willingness to participate without coercion, the existence of a trusting relationship between health workers and the community, intensive cooperation through direct presence and communication via gadgets. Also, openness and willingness to exchange information through village deliberations, supported by the value of caring for each other through information activities such as sick visits.

\section{The effect of bonding on social capital}

The results of the analysis in this study showed that bonding had a direct effect on social capital. There was a positive correlation between bonding and social capital and this effect was statistically significant.

Bonding refers to the social resources that a person can reach through a close network or group with similar demographic, social characteristics (Moore and
Kawachi, 2017). Social capital as social bonding has the basic characteristics of both groups and group members in ideas, relationships and more inward-oriented attention. Every individual of the same ethnicity, religion, origin, or identity has a high sense of moral obligation to help one another, help each other, and even give and receive (Abdullah, 2013).

\section{The effect of bridging on social capital}

The results of the analysis in this study showed that bridging had a direct effect on social capital. There was a positive correlation between bridging and social capital and this effect was statistically significant.

Bridging is a more diverse, outoriented network consisting of individuals with different social features and attributes. Due to its nature, dimensions (bridging) will facilitate access to external resources and information sharing (Gittell and Videl, 1998; Putnam, 2000). It refers to resources that can be accessed from networks or groups with different characteristics (Moore and Kawachi, 2017).

\section{The effect of linking on social capital}

The results of the analysis in this study showed that linking had a direct effect on social capital. There was a positive correlation between linking with social capital and this effect was statistically significant.

Linking norms of respect and correlation of trust in the status system connect individuals and groups in a hierarchy of power and authority (Moore and Kawachi, 2017).

According to Abdullah (2013), social capital as social linking effectively builds relationships and networks in groups with different social strata such as the people and government, superiors and subordinates, workers and employers. 


\section{The effect of trust on social capital}

The results of the analysis in this study showed that trust had a direct effect on social capital. There was a positive correlation between trust and social capital and this effect was statistically significant.

Several social capital elements include trust, reciprocal values and norms, institutions and associations, reciprocal relationships, and networks (Abdullah, 2013).

According to Maulidia and Hidayati (2019), trust (mutual trust), mutual help, and obeyed norms are assets in overcoming health problems. The existence of trust value can be seen from the community and health workers' involvement in all activities of the integrated healthcare center, Integrated Non-Communicable Disease Development Post, village deliberations, and home visits.

\section{AUTHOR CONTRIBUTION}

LailatulRohmah was the main researcher who played a role in collecting study data, formulating articles, and processing data. Setyo Sri Rahardjo played a role in the background formulation. Bhisma Murti helped to formulate a framework for learning and discussion.

\section{CONFLICT OF INTEREST}

There is no conflict of interest in this study.

FUNDING AND SPONSORSHIP

This study used private funds.

\section{ACKNOWLEDGEMENT}

The researchers would like to express their gratitude to the Director of Ponorogo Regional Public Hospital for providing a place to conduct this study so that this study can be carried out and to all patients who had been willing to be the respondents.

\section{REFERENCE}

Abdullah S (2013). Potensi dan kekuatan modal sosial dalam suatu komunitas. SOCIUS. 1(12).

Appleton AA, Loucks EB, Buka SL, Kubzansky LD (2014). Divergent associations of antecedent-and responsefocused emotion regulation strategies with midlife cardiovascular disease risk. Ann Behav Med. 48(2):246-55. doi: $10.1007 / \mathrm{s} 12160-014-9600-4$.

Kementerian Kesehatan Republik Indonesia (2013). Pedoman Pengendalian Stroke. Jakarta: Direktorat Pengendalian Penyakit Tidak Menular Kementerian Kesehatan Republik Indonesia.

Kementerian Kesehatan Republik Indonesia (2016). Pedoman Pengendalian Stroke. Jakarta: Direktorat Pengendalian Penyakit Tidak Menular Kementerian Kesehatan Republik Indonesia.

Marbun AS, Juanita, Ariani Y (2016). Hubungan antara stres dan gaya hidup dengan kualitas hidup pasien stroke. Jurnal Keperawatan Sriwijaya. 3(1).

Maulidia R, Hidayati K (2019). Program Indonesia sehat berbasis keluarga: kontribusi modal sosial keagamaan di masyarakat. Jurnal Penelitian Islam. 13(02): 233-25O. DOI: 10.21154/-kodifikasia.v13i2.1730.

Mutiarasari D (2019). Ischemic stroke: Symptoms, risk factors, and prevention. J Ilmiah Kedokteran. 6(1).

Moore S, Kawachi I (2017). Twenty years of social capital and health research: A glossary. BMJ. 71(5):513-517. doi: 10.1136/jech-2016-208313.

Monica W, Widyaningsih V, Sulaeman ES. (2019). Meta-analysis on the effects of hypertension, type II diabetes mellitus, and smoking on stroke risk among asian. J Epidemiol Public Health. 4(4): 296-306.https://doi.- 
org/10.26911/jepublichealth.2019.04.04 .04 .

Palafox B, goryakin Y, Stuckler D, Suhrcke $\mathrm{M}$, Balabanova D, Alhabib KF, Avezum A, Bahonar A, et al. (2017). Does greater individual social capital improve the management of hypertension? cross-national analysis of 61229 individuals in 21 countries. BMJ Glob Health. 2(4). doi: 10.1136/bmjgh-2017-000443.

Puluhulawa I (2019). Pengaruh faktor sosial ekonomi terhadap status kesehatan masyarakat di kecamatan palu selatan. e-Jurnal Katalogis. I(3): 1525.

Putnam RD (2000). Bowling alone: The collapse and a revival of American community. New York: Simon and Schuster.

Riset Kesehatan Dasar (2016). Hasil Riskesdas 2016. Jakarta: Riset Kesehatan Dasar.

Riset Kesehatan Dasar (2018). Hasil Riskesdas 2018. Jakarta: Riset Kesehatan Dasar.

Susilawati F, Nurhayati HK (2018). Faktor resiko kejadian stroke di rumah sakit. Jurnal Keperawatan. 14(1).
Udani G (2013). Faktor resiko kejadian stroke. Jurnal Kesehatan Metro Sai Wawai. 6(1).

Utami AS (2015). Manajemen psikologi dalam investasi saham kajian fenomenologi dalam sentuhan behavioral finance. Yogyakarta: Andi Offset.

Venketasubramanian N, Yoon BW, Pandian J, Navarro JC (2017). Stroke epidemiology in south, east, and south-east asia: A review. JOS. 19(3): 286-294.doi:10.5853/jos.2017.002-34.

Wardhani NR, Martini S (2014). Related factor of knowledge by stroke in institute of higher education employees. Jurnal Berkala Epidemiologi. 2(1).

World Health Organizations (2017). Noncommunicable Disease.

World Health Organizations (2018). Noncommunicable Disease.

Yulendasari R (2017). Hubungan antara aktivitas fisik dan hiperurisemia dengan kejadian stroke di RSUD dr. Hi. Abdul Moeloek provinsi Lampung tahun 2016. Jurnal Kesehatan Holistik. 11(2): 101-108. 